\title{
Filantropi Islam di Komunitas Muslim Tionghoa Surabaya: Ikhtiar Manajemen Zakat untuk Kesejahteraan dan Harmoni Sosial
}

\author{
Choirul Mahfud \\ Institut Teknologi Sepulub Nopember (ITS) Surabaya \\ choirul.mabfud@its.ac.id
}

\begin{abstract}
The Chinese Muslim community in Surabaya takes a role in various social activities, through Islamic philanthropy programs in the zakat aspect. This study using qualitative data from several observation, interviews, reference books, news, journals and opinions in mass media as well as other relevant sources. This study focuses on the following questions; how is the effort to optimize Islamic philanthropy in the zakat program for community welfare in the Chinese Muslim community in Surabaya?, how is the management of professional zakat efforts to realize the community in the Chinese Muslim community?, how to build zakat movement in Indonesia?. The results showed; the optimization of Islamic philanthropy in the Chinese Muslim community in Surabaya through the zakat program has been done, but still needs to be improved. Professional management of zakat is needed to realize society. How to involve a lot of professionals by using good management technology and systemic. Building the zakat movement in Indonesia among Chinese Muslim and non-Chinese Muslim and government partners to achieve optimal results.
\end{abstract}

Keywords: Chinese Muslim Community, Islamic philanthropy, Zakat management, and Social Harmony.

\begin{abstract}
Abstrak
Komunitas Muslim Tionghoa di Surabaya mengambil peran dalam berbagai kegiatan sosial, diantaranya melalui program filantropi Islam dalam aspek zakat. Penelitian ini dilakukan dengan menggunakan data kualitatif bersumber pada wawancara, referensi buku, berita, jurnal dan opini di media massa serta sumber lain yang relevan. Penelitian ini fokus pada pertanyaan, bagaimana upaya optimalisasi filantropi Islam dalam program zakat untuk kesejabteraan masyarakat di komunitas Muslim Tionghoa di Surabaya?, bagaimana upaya manajemen zakat profesional untuk mewujudkan kesejabteraan masyarakat di komunitas Muslim Tionghoa?, bagaimana upaya membangun gerakan zakat di Indonesia?. Hasil riset menunjukkan; optimalisasi filantropi Islam di komunitas Muslim Tionghoa di Surabaya melalui program zakat sudah dilakukan, namun masib perlu untuk ditingkatkan. Manajemen zakat profesional diperlukan untuk mewujudkan kesejabteraan masyarakat. Caranya dengan melibatkan banyak kalangan profesional dengan menggunakan manajemen teknologi yang baik dan sistemik. Membangun gerakan zakat di Indonesia memerlukan kerjasama antara masyarakat Muslim Tionghoa dan Muslim nonTionghoa dan pemerintah untuk meraih hasil optimal.
\end{abstract}

Kata kunci: Komunitas Muslim Tionghoa, Filantropi Islam, Manajemen Zakat, dan Harmoni Sosial.

Permalink/DOI: http://dx.doi.org/10.18326/infsl3v12i1.149-176 


\section{Pendahuluan}

Belakangan ini, komunitas Muslim Tionghoa di Indonesia, khususnya di Surabaya, memperoleh perhatian masyarakat karena kontribusinya dalam berbagai kegiatan sosial. Salah satu dari kegiatan sosial yang menarik diperhatikan adalah gerakan filantropi dan kegiatan amal. Di tingkat global, isu filantropi kembali memperoleh reaksi dan respon dari berbagai kalangan masyarakat luas. Nic Frances dalam bukunya "The End of Charity: Time for Social Enterprise", memberikan reaksi provokatif dan inspiratif yang mengilhami bagaimana kita berkenan memikirkan ulang gagasan tentang nasib filantropi dan gerakan amal, dengan berbagai alasan dan argumentasi untuk benarbenar mengatasi masalah kemiskinan, ketidakadilan, dan masalah ketidaksetaraan hidup. Frances nampaknya memiliki maksud baik dan menganjurkan kita semua untuk perlu ikut serta merespon sekaligus menjadi bagian solusi dari masalah yang ada. Strateginya bisa dengan menjadi wirausahawan sosial atau membangun bisnis sosial lain berbasis nilai manfaat nyata bagi masyarakat, sehingga tercipta masyarakat yang harmoni, adil dan sejahtera tanpa banyak problema yang berarti.

Namun faktanya harus diakui bahwa dunia ini memang selalu ada paradoks yang perlu diwaspadai bersama. John Naisbitt dan Thomas Hobbes memprediksi hubungan sosial-ekonomi pada masa mendatang akan mengalami fase yang disebut polarisasi ekonomi sekaligus terjadi berbagai paradoks. Fase ini ditandai dengan kecenderungan kultur manusia ke arah individualisme di mana sosok yang paling kuat adalah sebagai pemenang, homo bomini lupus. Dalam konteks ini, jika umat Islam di banyak negara meningkatkan kesadaran berzakat, dan mengoptimalkannya bagi kesejahteraan umat, maka mereka akan terhindar dari polarisasi ekonomi tersebut. Hubungan yang harmonis antara fakir miskin di satu pihak dengan kaum kaya di pihak yang lain akan terjelma tatkala zakat benar-benar dioptimalkan dan dimanfaatkan sebesarbesarnya untuk menjawab masalah sosial kemasyarakatan.

Berdasarkan observasi langsung di lokasi masjid Cheng Hoo Surabaya sebagai pusat aktivitas umat Islam di komunitas Muslim Tionghoa di Indonesia, khususnya di Surabaya, menyadari 
pentingnya ikut mengambil peran dan berkontribusi dalam gerakan filantropi Islam di Indonesia dan bahkan di tingkat dunia. Dari pengamatan tersebut di atas terlihat betapa kuat peran zakat dalam upaya menciptakan harmoni kehidupan dan kesejahteraan umat. Sayangnya, dalam realitas kehidupan saat ini, peranan zakat nampaknya belum optimal. Beberapa bukti di lapangan masih dijumpai beberapa ketimpangan dan mismanagement. Akibatnya, harmoni kehidupan dan kesejahteraan umat belum pada titik yang menggembirakan.

Masalah lainnya adalah kesadaran dan ketaatan kita dalam menjalankan perintah zakat masih jauh dari harapan. Padahal bukankah ajaran Islam itu rasional dan peduli masalah kemanusiaan? Sebagaimana diketahui bahwa perintah zakat sudah ditegaskan dalam kitab suci QS. at-Taubah 103:

"Ambillah zakat dari sebagian harta mereka, dengan zakat itu kamu membersibkan dan menyucikan ketenteraman jiwa bagi mereka. Dan Allab Maha Mendengar lagi Maha Mengetabui".

Dalam konteks ini, komunitas Muslim Tionghoa juga merasakan bahwa kesadaran zakat perlu diapresiasi lebih lanjut, sebab kewajiban zakat bagi orang kaya sama urgensinya dengan shalat bagi setiap umat Islam. Harta yang ada pada seseorang itu merupakan barang yang kotor sebelum dibersihkan dengan zakat. Zakat sebagai rukun Islam merupakan konsepsi Islam, yang harus diterjemahkan dalam dunia nyata. Zakat merupakan suatu sistem perekonomian mu'minin muslimin haruslah terefleksikan dalam kehidupan sehari-hari. Wujud kehidupan manusia dalam sistem zakat ini sebagai suatu kekuatan ekonomi Islam. Sayang menyayangi, dan berempati kepada mereka yang membutuhkan. Rumusnya adalah penataan faktor-faktor produksi yaitu alam, tanah, modal, tenaga kerja, ke dalam suatu kehidupan.

Berdasarkan al-Qur'an Surat at-Taubah: 60 bahwa ada 8 target dan sasaran dari aktivitas zakat yang dikumpulkan dan didistribusikan sesuai dengan aturannya, kepada: (1) fakir, mereka yang tidak mempunyai kemampuan dalam memenuhi keperluan dan kebutuhan hidupnya, (2) miskin, mereka yang tidak mampu mencukupi segala kebutuhannya, (3) amilun, para petugas 
zakat, (4) mualaf, mereka yang mengubah pandangan, sehingga mengalami berbagai kehancuran dalam ekonominya, (5) riqob, orang yang telah menghabiskan modalnya demi perjuangan untuk menegakkan "Nur" yakni al-Qur'an, (6) gharimin, orang yang sudah tenggelam dalam berbagai utang sebagai akibat dari pilihan hidupnya dengan al-Qur'an dan Sunnah, (7) fisabilillah, sebagai alat dan peralatan yang diperlukan guna menegakkan Islam, dan (8) ibnu sabil, mereka yang tanpa motif apa pun kecuali dengan tulus ikhlas mengabdi sepenuh hati menghabiskan umurnya guna menegakkan suatu kehidupan Islam menurut Sunnah Rasul.

Delapan golongan itulah yang berhak menerima zakat. Oleh karena itu, tunaikanlah zakat, karena sebagian harta orang kaya adalah hak orang miskin. Meningkatnya kelompok miskin di Indonesia pada dekade belakangan ini semakin mencolok. Angka barisan kelompok miskin semakin panjang setelah krisis yang terjadi di negeri ini silih berganti bagai mati satu tumbuh seribu. Untuk mengatasinya, pemerintah meluncurkan berbagai kebijakan seperti BLT (bantuan langsung tunai). Namun belum mampu meningkatkan derajat kehidupan masyarakat yang terlanjur sulit. Sebenarnya ada 4 (empat) variabel yang dominan memengaruhi pola pembagian pendapatan, sehingga terjadi disparitas yang cukup mencolok di negeri ini. Pertama, terjadinya kepincangan pertumbuhan ekonomi di segala sektor, terutama sektor yang ada di desa dan perkotaan. Kedua, alokasi tenaga kerja antara sektor industri dan pertanian. Ketiga, pola pemilikan kekayaan (assets) dan kecenderungan untuk menabung. Keempat, tingkat kemauan politik para pembuat kebijakan. Seharusnya, dalam kondisi inilah Islam tampil, sebagai musuh bagi mereka yang menumpuk kekayaan dan menyebarkan kesadaran hak yang miskin, lemah, dan tertindas.

Tatkala zakat berhasil didistribusikan secara efektif, maka diharapkan sebaran daya beli itu (effective demand) menjadi daya dorong yang kuat untuk sisi demand. Ini berarti aktivitas ekonomi akan terdongkrak yang pada gilirannya memberikan kesempatan kerja, terutama untuk kelompok miskin. Pergumulan aktivitas ekonomi seperti ini yang diharapkan dalam sistem zakat. Karena penumpukan modal (asset) pada satu orang atau kelompok, tidak akan memberikan kesejahteraan yang merata dan maksimal. 
Wujud harmoni kehidupan dalam sistem zakat seperti itulah yang dirindukan. Dalam komunitas Muslim Tionghoa, juga diyakini bahwa ajaran-ajaran Islam perlu juga dimaknai tidak hanya menghendaki seseorang memiliki capaian derajat kesalehan individual yang tercermin dalam ibadah-ibadah mahdloh (langsung) di satu sisi. Melainkan, Islam juga memerhatikan kesalehan sosial di sisi yang lainnya. Hikmah dan pelajaran yang bisa dipetik dari ibadah ritual tersebut sesungguhnya dimaksudkan tidak hanya untuk masingmasing individunya, tetapi juga perlu memiliki nilai tambah pada aktivitas sosial dalam masyarakat.

Kehadiran bulan suci ramadan bagi umat Islam seharusnya selain diyakini sebagai bulan yang penuh rahmat, maghfirah dan nikmat, juga perlu diniati sebagai upaya untuk memperbaiki relasi diri-sosial menuju level ketaqwaan (mutaqin). Sebab, kebanyakan agamawan lebih mendasarkan niatnya pada harapan mendapat syurga (takhali), dan gugur kewajiban ibadah (tahali) ketimbang semata-mata mencari ridha-Nya (tajjali). Di setiap bulan Ramadan tiba, kaum Muslim Tionghoa di Surabaya sama dengan kaum Muslim dimana saja yang meyadari bahwa kesadaran adanya kewajiban menjalankan ibadah puasa dan menunaikan zakat sebagai bagian dari gerakan filantropi Islam. Berbeda dengan puasa yang sering dimaknai secara individualistis, zakat memiliki arti sosial. Sebab, fungsi zakat bukan saja berfokus kepada kesucian diri, jiwa dan harta, tetapi juga peduli persoalan sosial kemasyarakatan sebagai upaya pengentasan kemiskinan dan kemajuan masyarakat.

Dengan zakat, berbagai permasalahan sosial bisa diminimalisir dan di atasi. Seperti, misalnya, angka pengangguran; berbagai sektor industri dan perdagangan bisa ditopang dengan dana zakat. Para mustahiq zakat bisa mengakses dana zakat untuk perkembangan dan kemajuan diri dan keluarganya melalui dana zakat yang tergulir dalam berbagai layanan pengembangannya. Dalam konteks di atas, tentu saja zakat harus dikelola dengan baik dan benar. Manfaat zakat sebagai perekat tali hubungan yang harmonis antara fakir miskin di satu pihak dengan kaum kaya di pihak yang lain akan terjelma manakala zakat benar benar dioptimalkan. Namun dalam realitasnya, peranan zakat belum optimal dan belum terlaksana sesuai yang 
diharapkan. Ketimpangan dan mis-management, bahkan ketaatan kita dalam membayar perintah zakat masih jauh dari harapan. Padahal selain perintah agama, Indonesia juga mempunyai Undangundang (UU) terkait zakat.

Ironis sekali, bukan? Padahal, secara kuantitas, penduduk muslim di negeri ini tidak sedikit. Manakala, dana zakat dikelola dengan baik, maka masalah sosial seperti tersebut di atas bisa segera diatasi. Dalam konteks meningkatnya angka pengangguran dan kemiskinan bisa jadi disebabkan salah urus dana zakat. Ini termasuk masalah dan tantangan untuk membuktikan bahwa zakat bisa menjadi solusi sekaligus institusi strategis untuk mewujudkan tatanan ekonomi yang sistemik, adil dan amanah. Harapannya, zakat bukan seperti yang penulis sebut di atas hanya sekadar menyucikan jiwa dan harta, atau bermakna karitatif. Namun, juga mendukung adanya nuansa dan iklim ekonomi islami yang berbasis keadilan, kemaslahatan dan kesejahteraan yang disebut Monzer Kahf sebagai distribusi harta yang egaliter. Berdasar syariah Islam, zakat merupakan jawaban standar tertentu terkait kepemilikan harta benda yang dimiliki untuk ditunaikan secara tulus ikhlas untuk dibagikan kepada siapa saja yang berhak (diantaranya, wajib disantunkan kepada fakir miskin, amil zakat, musafir dan muallaf). Apapun yang diberikan atau dizakatkan tentusaja hal ihwal yang telah dipersyaratkan sebagaimana ketentuan al-Qur'an untuk menggapai ridho Allah SWT melalui aktivitas berbagi antar sesama umat manusia.

Dalam praktiknya, secara umum dikenal dua macam zakat, yaitu: zakat fitrah dan zakat maal (harta). Namun, belakangan ini ada satu lagi jenis zakat yang fenomenal dibahas ulama, yaitu: zakat profesi. Jenis zakat ini merupakan tanggungjawab pribadi yang bekerja dan memperoleh gaji atau pendapatan. Hasil gaji tersebut ada sebagian hak yang perlu ditunaikan atau dizakatkan. Disini, pembahasan zakat profesi masih terus diperdebatkan dengan pajak. Namun, intinya semua pihak, terutama ulama dan umat Islam sependapat bila ada zakat profesi untuk berbagi dan saling peduli. Pembahasan zakat biasanya beriringan pada momentum ramadhan. Hal ini, terutama, bahasan zakat fitrah atau maal. Di bulan Ramadan, 
ada kewajiban bagi seorang muslim untuk membayar zakat fitrah atau maal. Tujuan utamanya bukan saja untuk menunaikan kewajiban, tetapi juga untuk mensucikan diri lahir dan bathin. Problem kemiskinan bagian dari masalah yang tidak sejalan dengan humanisme dan spiritualisme Islam. Kemiskinan diasumsikan bisa membuat orang berbuat yang tidak sejalan dengan ajaran Islam. Di sinilah, kemiskinan bisa menjadi faktor pemicu dan pemacu individu berbuat keburukan dan kemunkaran, radikalisme, ekstremisme, dan lainnya. Sebagai upaya antisipasi, Islam memahami berbagai faktor masalah anti humanisme semacam itu dengan solusi yang lebih humanis melalui zakat.

Humanisasi dalam ajaran Islam merupakan salah satu kata kunci (keyword) dalam menjaga hubungan baik antar sesama manusia. Islam mengajarkan keseimbangan (equilibrium), pentingnya menyadari keseimbangan menjalin kasih hubungan kepada Tuhan (Allah SWT) sekaligus berusaha semaksimalnya berhubungan baik dengan manusia dan alam semesta. Di sinilah, problem kemiskinan sebagai pemicu kemunkaran perlu diantisipasi dengan solusi amal nyata untuk bersama. Dalam kehidupan Islami, tentu kita tidak ingin terjadinya teori Hobbesian yang cenderung menghalalkan segala macam cara dan cenderung menindas satu dengan lainnya tanpa ada pertimbangan kemanusiaan. Selain pijakan etika religius di atas, kita berharap kepada Tuhan Kuasa melalui pemerintah, masyarakat dan institusi Badan Amil Zakat, Infaq dan Shodaqoh (BAZIS) yang menjadi lembaga manajemen zakat, untuk terus serius, peduli, dan profesional dalam mengorganisir program pemberdayaan umat dengan melibatkan semua elemen stakeholders dan shareholders, dengan berbagai langkah dan usaha penguatan, pelatihan dan partisipatori umat, sehingga kehadiran agama membawa manfaat nyata sebagai solusi humanisasi dan transformasi dalam mewujudkan keadilan, menciptakan kemakmuran, dan kesejahteraan.

Tulisan ini dimaksudkan untuk menjawab beberapa pertanyaan penting sekaligus menawarkan solusi alternatif apakah zakat sudah dioptimalisasikan di komunitas Muslim Tionghoa di Surabaya atau di Indonesia secara umum? Manakala belum maksimal, bagaimana upaya dan strategi jitu yang bisa ditempuh umat Islam kini dan esok? 


\section{Metode Penelitian}

Jenis penelitian yang digunakan dalam penelitian ini adalah penelitian deskriptif kualitatif yang bersumber pada pengamatan, wawancara, dokumen, referensi buku, berita, jurnal dan opini di media massa serta sumber lain yang relevan. Penelitian ini dilakukan berdasarkan pada permasalahan yang muncul dalam manajemen zakat sebagai bagian dari filantropi Islam di komunitas Muslim Tionghoa di Surabaya. Untuk lebih memahami masalah dalam penelitian ini, prosedur pelaksanaan penelitian dengan menggunakan sejumlah teknik pengumpulan data, yaitu: (1) Observasi/Pengamatan untuk melihat langsung kegiatan komunitas muslim Tionghoa di Surabaya dalam filantropi Islam. (2) Dokumentasi. Dalam mencari sumber informasi melalui studi dokumentasi peneliti mengumpulkan dan menyelidiki benda-benda tertulis seperti buku, dokumen, catatan harian, berita, opini, buku, jurnal, artikel dan sebagainya. Semua itu diolah dan dianalisis untuk memahami topik kajian dalam penelitian.

\section{Hasil dan Pembahasan}

\section{Peluang Filantropi Islam di Komunitas Muslim Tionghoa}

Dari masa ke masa, potret komunitas Muslim Tionghoa di Indonesia cukup menarik diperhatikan. Termasuk tantangan sekaligus peluang zakat bagi umat Islam Tionghoa di Indonesia, khususnya di kota Surabaya. Secara umum, tantangan yang dihadapi adalah masih sedikitnya orang Tionghoa yang memeluk agama Islam turut mempengaruhi perkembangan gerakan zakat di komunitas Muslim Tionghoa. Namun begitu, gerakan filantropi di komunitas muslim Tionghoa bersifat terbuka. Artinya, donasi dan sumber zakat tidak saja bersumber dari umat Islam Tionghoa, tetapi juga terbuka bagi umat Islam non-Tionghoa yang berkenan menjadi donatur atau muzzaki. Di lain sisi, ini menjadi peluang bagus dan baru bagi komunitas Muslim Tionghoa untuk membuka pintu bagi saudara non-Muslim Tionghoa yang ingin beramal melalui program amal, dan peduli sosial. Dalam hal ini, gerakan filantropi Islam di komunitas Muslim Tionghoa di Surabaya cukup menarik diperhatikan. 
Diakui bahwa gerakan filantropi Islam Tionghoa hampir sama juga dengan gerakan Islam non-Tionghoa pada umumnya yang masih menghadapi sejumlah tantangan dan peluang di level global, nasional dan lokal. Di tingkat global, desakan masyarakat internasional untuk mencapai Millennium Development Goals (MDGs), yakni menghapus kemiskinan dunia hingga separuh pada tahun 2025, tampaknya sulit diwujudkan jika secara politik nasional maupun global tidak memberi gerak lebih baik bagi orang miskin untuk mengakses pemenuhan kehidupannya secara adil. Jamak diketahui, kemiskinan di Indonesia sebenarnya buah politik pemiskinan yang sudah berjalan lama. Orang miskin bukan karena dirinya yang menyebabkan miskin, tetapi ada faktor politik pemiskinan yang dilakukan para penguasa bergandengan dengan kelas pemodal.

Dalam konteks ini, umat Islam Tionghoa di Surabaya meyakini bahwa zakat bisa menjadi institusi strategis bagi pembebasan orang miskin yang dimiskinkan penguasa dan pemodal. Inilah yang harus dilihat, penunaian zakat bukan hanya dilakukan secara karikatif sebagai ekspresi keagamaan instan. Setelah menunaikan zakat, sebagai orang kaya kembali dengan modalnya melakukan perilaku pemiskinan. Dalam hal ini, zakat tidak akan memberi efek strategis apa pun, tetapi lebih banyak menyentuh kesadaran psikologis; membuat orang miskin senang, terhibur, dan merasa tenteram. Memberi sebagian kecil hartanya di bulan Ramadan adalah perbuatan baik, tetapi mengeruknya kembali secara tidak adil adalah perbuatan nista. Menurut Yusuf Qardawi (1999) bahwa salah satu yang diharapkan Islam dengan ajaran zakat adalah adanya perubahan dalam sistem dan perputaran kekayaan yang ada di masyarakat.

Sebagian umat Islam Tionghoa di Surabaya menyadari bahwa hal ini merupakan tantangan sekaligus peluang bagi siapa saja untuk lebih memaknai zakat sebagai institusi strategis dalam mendukung terciptanya tatanan ekonomi Islam yang lebih sistemik, adil dan amanah. Dalam ajaran Islam, Gazi Inayah (1995) mengungkapkan bahwa zakat memiliki dua makna, teologis-individual dan sosial. Makna pertama menyucikan harta dan jiwa. Penyucian harta dan 
jiwa bermakna teologis-individual bagi seseorang yang menunaikan zakat untuk mereka yang berhak. Jika makna ini dipedomani, ibadah zakat hanya berdampak individual, yakni hubungan vertikal antara seorang hamba dengan Tuhannya. Kategori makna pertama lebih bernuansa individual, menyucikan harta dan jiwa agar dapat meraih berkah.

Sedangkan, kategori yang kedua mempunya dimensi sosial, yang bisa dipahami sebagai upaya menjawab masalah patologi sosial, seperti problem ketidakadilan ekonomi dan kemiskinan. Melalui berbagai usaha berbasis zakat, maka diasumsikan terjadi relasi dan sirkulasi kekayaan antar sesama. Dalam hal ini, yang kaya bisa berbagi dengan yang miskin. Jalinan hubungan yang baik dan manfaat tentu saja dapat menciptakan tatanan masyarakat yang damai, maju dan sejahtera. Ibnu Khaldun pernah menyatakan bahwa kepemilikan harta benda itu melahirkan hubungan sirkuler antara raja/ penguasa dan warga/ rakyat. Namun, yang disayangkan seringkali hubungannya kurang berjalan dengan setara dan basis ekonomi masyarakat tidak imbang. Statistika zakat bisa menunjukkan trend yang seperti diharapkan. Dalam hal ini, perintah zakat dalam Islam merupakan salah satu agenda penting untuk saling berbagi kebahagiaan, kenikmatan rizki antar sesama manusia. Dalam kacamata ekonomi ini, istilah ini biasa dikenal dengan upaya pemerataan ekonomi. Jadi tidak melulu terjadi penumpukan kekayaan di tangan segelintir orang pemilik kapital.

Dalam konteks ini, kesadaran zakat dan gerakan filantropi Islam di komunitas Muslim Tionghoa di Surabaya memiliki sejumlah peluang yang sangat besar disamping adanya tantangan yang ada. Peluang semacam ini perlu terus dioptimalisasi untuk keperluan dan kepentingan membangun kekuatan ekonomi umat Islam Tionghoa khususnya dan umat Islam di Indonesia pada umumnya untuk mendukung kemajuan bangsa.

\section{Muslim Tionghoa Menghindari Jebakan Kapitalisme}

Komunitas muslim Tionghoa di Surabaya berkomitmen dalam gerakan filantropi Islam sebagai bagian upaya menghindari jebakan 
kapitalisme dimana yang kaya semakin kaya dan yang miskin terus dalam kondisi miskin. Gagasan Zakiyuddin Baidhawy dalam buku "Islam Melawan Kapitalisme; Konsep-konsep Keadilan dalam Islam", menarik dihadirkan disini bahwa sistem dan etika ekonomi Islam (termasuk dalam komunitas Islam Tionghoa) bisa menjadi solusi alternatif untuk menjawab problematika ketidakadilan ekonomi yang melanda peradaban dunia saat ini. Bagi Zakiyuddin, problem ketidakadilan itu terjadi karena dunia saat ini menganut sistem ekonomi yang berlandaskan kapitalisme. Dalam konteks ini, apa yang dilakukan umat Islam khususnya di komunitas Islam Tionghoa melalui program filantropi Islam khususnya dalam program zakat dan peduli sosial bisa menjadi jawaban untuk melawan sistem kapitalisme. Melalui gerakan zakat, misalnya, yang kaya bisa berbagi dengan yang miskin, sehingga bisa merasakan efek positif adanya gerakan zakat.

Dalam upaya pengentasan kemiskinan yang menjadi substansi ajaran zakat sering dijumpai perilaku yang bertolak belakang, yakni menggunakan agama sebagai kedok untuk memperkaya diri (kapitalisme), sekaligus juga berperilaku korupsi. Makna penyucian harta dan jiwa dalam zakat sering disalahartikan oleh mereka yang berduit (aghniya) dan berkuasa alias pejabat. Efeknya, zakat di bulan Ramadan rasanya dijalankan untuk menyucikan harta hasil korupsi dan praktik kemaksiatan lainnya yang tentu tidak sejalan dengan misi ajaran zakat. Oleh karena itu, perintah zakat tergerus makna dan arti esensinya. Idealnya ajaran zakat bisa menyadarkan kita untuk lebih giat bekerja untuk dunia dan akhirat. Juga, dengan berzakat kita semakin peduli antar sesama. Bahkan, mendorong kita untuk semangat meraih rizki yang halalan thoyibban dalam rangka memperoleh ridho-Nya.

Komunitas Islam Tionghoa di Surabaya semakin lama semakin bagus dan memperoleh apresiasi dari berbagai kalangan. Hal ini merupakan bagian dari keberlanjutan dan perubahan zaman. Perkembangan dan perubahan zaman dalam berbagai bidang kehidupan meniscayakan agama dan umatnya mampu memberikan solusi jawaban dan jalan tengah untuk memenuhi harapan, kebutuhan dan keinginan publik. Dalam buku Pradana Boy ZTF 
(2008) tentang Fikih Jalan Tengah: Dialektika Hukum Islam dan Masalah-masalab Masyarakat Modern, dipaparkan pandangan prokontra sekaligus ditawarkan win-win solution berdasarkan hukum Islam mengenai persoalan kontemporer yang dihadapi umat Islam, termasuk diantaranya perlunya menempuh jalan tengah masalah zakat di Indonesia.

Khamami Zada (2005) pernah mengungkapkan bahwa masalah zakat seringkali dipahami secara formalistik yang dakal esensinya dan tidak memperdulikan makna hakiki ajaran agama. Zada menganjurkan kita untuk benar-benar memahami segala asal usul harta yang diperoleh. Bila cara memperolehnya tidak baik dan tidak halal, maka seyogyanya dipikir ulang untuk tidak dilakukan. Praktik korupsi yang cenderung tidak sesuai dengan maksud dan harapan ajaran agama tentu merugikan diri dan semuanya yang perlu diupayakan untuk dihindari sebisanya. Menurutnya, agama jangan dimanfaatkan untuk menghalalkan praktik korupsi dengan cara membayar zakat. Justru, agama memberi justifikasi dan solusi teologis, bahwa mereka yang bertindak korupsi sama saja berbuat dosa. Akibatnya tentu bukan meraih kebahagiaan dan keberkahan, namun kesusahan dan kesedihan yang tentu tidak diharapkan.

Bukankah harta hasil tindakan korupsi adalah uang umat dan masyarakat. Meskipun dizakatkan tentu saja tetap bermasalah, karena asal usul dan cara memperolehnya tidak sesuai dengan yang diperintahkan dalam ajaran agama. Justru sebelum berzakat, seorang muslim diharapkan bukan saja menjalankan apasaja yang diperintahkan, tetapi juga diminta untuk menjauhi laranganlarangan Allah SWT. Di sinilah, fungsi dan peran agama berlipat ganda. Agama tidak saja memberikan solusi, tetapi juga antisipasi. Semua itu untuk menuju dan meraih kedamaian, kebahagiaan dan keselamatan. Dalam optik ini, masalah korupsi merupakan bagian jebakan budaya kapitalisme negatif yang bisa dimaknai sebagai pengabaian terhadap hak-hak orang miskin. Kapitalisme negatif semacam ini perlu diwaspadai bersama. Caranya melalui berbagai upaya penyadaran dan pemberdayaan berbasis masyarakat sesuai ajaran Islam yang mengedepankan visi, misi dan target untuk kerahmatan bagi semua umat manusia. Karenanya, umat Islam Tionghoa dalam komunitas Muslim Tionghoa di Surabaya memaknai 
ulang zakat untuk transformasi masyarakat diperlukan untuk lepas dari jebakan kapitalisme, kebodohan, kemiskinan dan ketidakadilan menuju masyarakat madani.

\section{Memaknai Ulang Zakat}

Bagi umat Islam Tionghoa di komunitas Muslim Tionghoa di Surabaya, pemahaman tentang zakat merupakan sesuatu yang baru dan bagus untuk menyebarkan agama Islam dengan penuh kepedulian bagi sesama. Pemahaman umat Islam Tionghoa di Surabaya juga terus dilakukan melalui berbagai program kajian, diskusi dan dialog melalui forum pengajian mingguan maupun lainnya. Bahkan juga pengkajian tentang masalah keislaman juga dilakukan melalui forum media sosial.

Umat Islam Tionghoa di Surabaya juga menyadari bahwa mengkaji ulang konsepsi zakat untuk meraih tujuan mulia sesuai dengan misi ajaran agama Islam tentu bagian ijtihad yang diharapkan. Inilah yang belakangan disumsikan senafas dengan maqashid syariah. Sebagian prinsip utamanya adalah saling tolong menolong. Berdasarkan syariah pula, zakat sebagai bagian filantropi Islam merupakan sejumlah kadar tertentu dari "harta" milik yang wajib diberikan atau ditunaikan kepada siapa saja yang berhak memperolehnya. Istilah "harta" di sini yaitu apasaja yang terkait dengan kebendaan yang dimiliki nilai ekonomis dan produktif. Dalam realitasnya, zakat fitrah dan zakat maal menjadi pembahasan utama.

Di kalangan fuqaha, pembahasan zakat masih didefinisikan sebagai sebutan dari kadar harta tertentu yang wajib dibagikan untuk pihak-pihak tertentu pula. Padahal, zakat bukan semata pengambilan atas "kelebihan" harta tertentu sebagai alat 'penyuci'. "Ambillah zakat dari sebagian harta mereka, dengan zakat itu kamu membersibkan dan menyucikan mereka..." (QS. At Taubah: 103). Lebih dari hal itu, pembicaraan zakat sebetulnya memiliki komitmen spiritualitas, kerohanian keagamaan yang langsung bersentuhan dengan kehidupan sosial umat manusia. Ia tidak sama persis dengan pajak atau upeti dan sejenisnya. Ia betul-betul perintah yang di dalamnya terkandung semangat kesejahteraan umat dan keadilan dalam kehidupan sosial. Karenanya, Allah SWT. 
menegaskan bahwa sasaran utama zakat adalah kaum fakir dan umat miskin, muallaf, dan budak yang tertindas (duafa).

"Sesungguhnya zakat-zakat itu hanyalah untuk orang-orang fakir, miskin, muallaf, untuk memerdekakan budak, orang-orang yang berutang..." (QS. At Taubah: 60).

Dalam konteks ini, ternyata masih ada kekeliruan persepsional cukup mendasar yang menjalar di kalangan kaum muslim Indonesia. Mereka telah meneguhkan bahwa harta dan kekayaan yang dimiliki saat ini benar-benar karena jerih payahnya sendiri. Kesadaran sosial seperti ini sangatlah jauh dari nilai penghambaan. Itulah yang melahirkan kesombongan dan keangkuhan umat manusia di hadapan Allah SWT. Bahkan, kesadaran parsial seperti itu, diakui atau tidak, telah menyebabkan diskriminasi atau kerusakan sosial. Yang kaya semakin kaya dan rakus mengeksploitasi serta mencekik yang miskin. Bagi yang melarat semakin melarat-miskin. Keadilan semakin jauh panggang api. Padahal, agama telah mengajarkan kepada kita bahwa seluruh harta dan kekayaan lain yang kita miliki di muka bumi ini hanyalah amanah dari Allah. Dalam hal ini, praktik ekonomi Islam tentu saja kembali dipersoalkan terkait bahasan zakat.

Sebagaimana diketahui bahwa al-Qur'an sejak awal menyatakan bahwa di setiap harta dan kekayaan yang kita miliki, terdapat rezeki dan hak kaum dhu'afa. Karena itu, harta dan kekayaan itu harus dibersihkan dengan cara mengeluarkan zakat. Dan setiap mengeluarkan zakat dari harta atau kekayaan lain yang kita miliki merupakan langkah penyelamatan kehidupan setiap manusia di dunia maupun di akhirat nanti. Allah SWT dengan tegas menyatakan bahwa di antara orang-orang yang akan celaka itu bukan saja mereka yang menyia-nyiakan fakir miskin dan anak yatim. Akan tetapi, kecelakaan yang lebih dahsyat akan menimpa mereka yang tidak mau mengeluarkan zakat. Dan mereka itu oleh Allah disebut sebagai orang yang musyrik.

"Dan celakalah bagi orang-orang musyrik yaitu orangorang yang tidak mengeluarkan zakat" (Q.S.Fussilat 7, dan Q.S. as-Sajadah: 6-7). 
Tidak sedikit orang berharta lantaran jarang mengeluarkan zakat, kekayaannya bukan mendatangkan kebahagiaan melainkan menindihnya dengan penuh penderitaan. Harta sebanyak apa pun tidak akan pernah dibawa dan ditanya Allah di alam kubur nanti. "Jangan kamu mengira orang-orang yang bakbil atau kikir dengan apa yang diberikan Allah pada mereka dari kekayaan itu, baik bagi mereka, babkan bahaya bagi mereka. Sebab kekayaan itu akan dikalungkan ke leher mereka pada hari kiamat" (Q.S. Ali Imran: 180). Zakat akan mengarahkan manusia pada jalan kebenaran yang diridhai Allah. Mereka tidak akan tamak, rakus, dan memanipulasi hak-hak orang lain, terutama harta kaum miskin. Zakat akan melatih setiap orang untuk memahami dan menyadari betul bahwa dalam setiap harta yang diberikan Allah selalu tersimpan nilai-nilai spiritual keagamaan. Zakat adalah praktik riil menegakkan keadilan sosial. Pertanyaannya, bukankah menegakkan keadilan sosial itu merupakan peringkat tinggi ketaqwaan manusia.

Zakat dalam konteks ini, akan menjaga keseimbangan sosial perekonomian masyarakat. Itulah salah satu nilai spiritualitas zakat. Ketimpangan sosial tidak akan menjadi kemelut yang terus berlanjut. Kriminalitas, perampokan, penjarahan, penimbunan dan lain sebagainya, tidak akan terjadi selama kita memahami betul nilai-nilai spiritual yang ada dalam setiap harta dan kekayaan kita. Intinya, kesadaran spiritualitas zakat, dapat dipastikan mampu mendidik manusia lebih siap menyelesaikan penderitaan sosial perekonomian masyarakat, bangsa, dan negara.

Bagi mereka yang memiliki paradigma sosial pragmatis. Beribadah dengan harta kekayaan, terkadang teramat sulit dan begitu berat mengingat perjuangannya juga berat. Meskipun kalau dikalkulasi secara mendalam ketentuan yang diberlakukan persentasenya sangat kecil hanya $1 / 40$ atau 2,5\%. Sedangkan, yang tersisa dari prosentase harta kita itu adalah 39 bagian. Di pihak lain, masih sangat banyak varian rezeki dari Allah yang kita terima dan tidak terkena ketentuan zakat. Sungguh, jika hal itu terjadi, betapa tidak adilnya kita terhadap diri dan lingkungan masyarakat kita. Di sinilah kontekstualisasi spiritualitas zakat menemukan relevansinya. Ramadan, selayaknya dijadikan momentum paling bermakna untuk 
menggerakkan hati dan menyucikan harta maupun diri kita sebagai manusia. Bukankah Allah menegaskan bahwa:

"Sesunggubnya orang-orang yang beriman hanyalab orangorang yang beriman kepada Allab dan Rasul-Nya. Kemudian, mereka tidak ragu-ragu dan mereka berjihad dengan harta dan jiwa mereka pada jalan Allah, mereka itulah orang-orang yang benar" (Q.S. Al-Hujurat: 15).

Dalam hal ini, Allah SWT. senantiasa menghubungkan salat dan zakat. Kedua perintah itu, dalam al-Qur'an selalu memperlihatkan dirinya sebagai "induk" dari seluruh "jalan" keislaman. Sedangkan Rasul meletakkan keduanya sebagai rukun Islam setelah pengakuan keesaan Tuhan. Salat adalah untuk meneguhkan keislaman pada dimensi spiritualitas personal. Zakat adalah aktualisasi keislaman terkait dengan realitas sosial. Menurut H. Syarief Muhammad (2006) bahwa beragama yang baik ialah melaksanakan segala ritual dengan istiqamah, dan mematangkan maknanya dengan sikap sosial nyata demi kemaslahatan manusia. Di sini, antara aspek ilahiah dan insaniah diharapkan seimbang. Ajaran Islam mendorong umatnya untuk berlomba-lomba bukan dalam keburukan, tetapi dalam kebaikan, termasuk dalam berzakat atau beramal sholih. Dalam bahasa modern, zakat merupakan tanggungjawab sosial dari individu seorang muslim-muslimah. Zakat juga untuk menghindari gap, konflik dan berbagai ketimpangan sosial, ekonomi, budaya dan lainnya. Bahkan, dalam banyak hal, fungsi dan peran zakat bisa menumbuhkan rasa solidaritas dan kepekaan sosial yang tinggi dan kuat dalam diri yang beramal atau pelakunya. Hal ini terlihat dari aktivitas berzakat di berbagai lokasi masjid di Indonesia, termasuk masjid Cheng Hoo Surabaya yang memiliki berbagai agenda sosial keagamaan.

Dalam konteks ini, Harahap (1999) menyatakan bahwa prospek pembangunan umat berbasis zakat merupakan salah satu mekanisme utama dalam pemberantasan kemiskinan dan peningkatan kesejahteraan publik. Rasanya ini termasuk potret dan kondisi objektif kebutuhan dan harapan sebagian besar umat Islam dimana saja. Intinya yang dimaksudkan yaitu bagaimana mengupayakan kebaikan, kemandirian dan kesejahteraan umat 
dalam bidang ekonomi, sosial, budaya dalam mekanisme dan sistem zakat. Ajaran zakat memiliki filosofi yang kuat bila dipahami dari dalil naqli dan aqli yang intinya bukan bermaksud memaksa tanpa tujuan. Justru banyak argumentasi, ulasan dan alasan kenapa zakat menjadi ajaran fenomenal dalam Islam. Ketika setiap pribadi mempraktikkan ajaran zakat, sesungguhnya tidak membuat dirinya rugi, justru setiap pelakunya merasakan ketenangan, ketentraman dan kebahagiaan seperti halnya yang dirasakan penerima zakat. Dalam praktiknya, ada semacam titik temu antara teori dan praktik. Bukan lagi ada semacam dikotomi ajaran yang berhenti di level wacana semata. Justru, banyak sekali ajaran praktis yang bermanfaat dan berimplikasi positif bagi seluruh elemen kehidupan.

Dalam posisi ini, kedudukan zakat sangat fundamental bagi usaha menjaga agama dengan cara mengamalkan ajarannya. Seiring perkembangan zaman dan perubahan ekonomi yang ada, banyak sekali ulama dan ahli agama mencoba mengkaji ulang total kuantitas kewajiban berzakat sebesar 2,5\% per jiwa. Bahkan, juga ada semacam tafsir ulang pemanfaatan zakat bisa lebih dikembangkan dan disalurkan dalam area kawasan tanpa batas di seluruh dunia ini. Harapannya, gerakan zakat tidak lagi dipahami secara sempit, tetapi ada makna dan tujuan serta harapan yang lebih luas dan bermanfaat bagi seluruh alam semesta. Prinsipnya, zakat perlu terus diupayakan untuk dikembangkan dari berbagai sisi manajemen, input, proses, output dan outcome-nya. Pada akhirnya, kita juga akrab dengan istilah zakat yang efektif dan produktif. Semua usaha itu terutama dimaksudkan sebagai upaya optimalisasi zakat untuk menjawab kebutuhan, masalah, tantangan dan perkembangan zaman bagi umat Islam Tionghoa khususnya dan umumnya bagi masyarakat Islam lainnya serta bagi seluruh masyarakat bangsa Indonesia.

\section{Optimalisasi Zakat di Komunitas Muslim Tionghoa}

Umat Islam Tionghoa di Surabaya menyadari bahwa saat ini diperlukan optimalisasi zakat untuk umat. Optimalisasi filantropi Islam, khususnya zakat infaq dan shadaqah, merupakan tuntutan dan harapan masyarakat untuk terus dikampanyekan untuk menggalang potensi dari dalam umat Muslim di dunia, termasuk 
di Indonesia. Indonesia merupakan negara yang berdaulat berbasis Pancasila sebagai pilar ideologis, Undang-Undang Dasar 1945 yang menjadi landasan yuridis, Bhinneka Tunggal Ika sebagai potret sosial budaya, dan Negara Kesatuan Republik Indonesia sebagai cita-cita bangsa. Indonesia juga dikenal sebagai negeri multikultural dengan jumlah penduduk yang dominan memeluk Islam terbesar. Namun, disadari bahwa optimalisasi zakat belum dilakukan sesuai yang diharapkan, termasuk dalam komunitas Islam Tionghoa. Masih ada sejumlah pekerjaan rumah yang perlu dikerjakan. Terbukti, masih ada saja masalah yang dihadapi dan dijumpai dari sisi manajemen pengelolaan dan lainnya. Padahal, pemerintahan Indonesia juga memiliki Undang-undang (UU) tentang zakat. Bila dibandingkan dengan Malaysia, ternyata malah Malayisa yang bisa dikatakan lebih berhasil terkait pengelolaan zakat. Tentu ini bukan kabar baik bagi Indonesia yang diharapkan menjadi contoh ideal bagi masyarakat dunia. Oleh karena itu, tidak ada jalan lain kecuali semua pihak perlu ambil peran dalam optimalisasi zakat sebagai sumber dana umat untuk mendukung terwujudnya masyarakat harmoni dan sejahtera.

Mas'udi menjelaskan bahwa efektivitas manajemen optimalisasi zakat perlu dikaji ulang dengan berbagai solusi dan alternatif, sehingga bisa dirasakan maslahat dan manfaatnya bagi umat. Gagasan Mas'udi memang beralasan melihat berbagai problem terkini umat Islam dalam kehidupan sehari-hari yang bisa dicari solusinya melalui institusi zakat. Rasanya, masih jarang di hati dan pikiran masyarakat bahwa ketika ada masalah ekonomi, maka bisa kembali ke lembaga zakat. Ke depan, institusi zakat bisa saja menjadi daya tarik bagi siapa saja, baik yang mau berzakat atau yang konsumen pengakses zakat.

Seperti di Malaysia, ketika ada sebagian umat Islam yang kesulitan ekonomi dan terjepit serta terjerat berbagai masalah kehidupan, kehadiran dan keberadaan lembaga zakat bisa dirasakan. Hal itu telah menjadi berita baik yang perlu dihayati. Kasus riilnya di Malaysia, diantaranya, saat ada yang sakit dan tidak bisa membayar, umat Islam di negeri Jiran tersebut tidak pergi ke Bank, tetapi menghubungi lembaga zakat terdekat yang memberikan pelayanan bagi warga muslim yang memiliki kesulitan dan masalah keuangan. 
Tentu saja dimungkinkan solusinya diambil bukan saja dari zakat, tetapi juga bisa dari dana infaq atau sedekah dalam menjawab masalah tersebut.

Di Indonesia, kita tahu sama tahu bahwa Undang-Undang zakat sudah dituangkan dalam UU No. 17 tahun 2000 tentang pengelolaan zakat. Pertanyaannya, bagaimana dampak dari kebijakan regulatif dari Undang-Undang tersebut? Tentu saja ada, tetapi sayangnya belum optimal. Oleh karena itu, perlu dilakukan langkah berkelanjutan untuk terus mengevaluasi hingga mengoptimalisasinya.

Problem lain yang perlu terus diperhatikan yaitu soal kepercayaan (trust). Kepercayaan termasuk modal sosial yang sangat penting dan berharga bagi siapa saja, termasuk bagi institusi pengelola zakat BAZ (Badan Amil Zakat) dan LAZ (Lembaga Amil Zakat). Faktanya bahwa tidak semua lembaga zakat dengan mudah memperoleh amanah dan kepercayaan di hati masyarakat. Oleh karena itu, saat ini akreditasi dan sertifikasi lembaga zakat kini menjadi solusi jalan keluar yang mulai dijadikan acuan untuk membangkitkan rasa kepercayaan masyarakat terhadap lembaga zakat di Indonesia. Pada point ini, akreditasi dan sertifikasi lembaga zakat merupakan langkah awal yang jelas dan memiliki dampak nyata bagi upaya meningkatkan statistik kepercayaan umat Islam. Tanpa kepercayaan, semua usaha yang dilakukan rasanya lebih berat. Sebaliknya, dengan modal kepercayaan, apapun bisa dilakukan dengan hasil yang lebih sesuai dengan harapan. Memang diakui bahwa untuk meraih tingkat kepercayaan publik yang tinggi, perlu proses dan langkah yang maksimal. Karena itu, segala upaya kerjasama, sinergi dan sosialisasi menjadi penting dilakukan.

\section{Manajemen Zakat Melalui Masjid Cheng Ho Surabaya}

Umat Islam Tionghoa di Surabaya melakukan berbagai upaya manajemen zakat melalui masjid dan yayasan Haji Muhammad Cheng Hoo Surabaya, dan Persatuan Islam Tionghoa Indonesia (PITI). Namun disadari bahwa upaya manajemen ini merupakan upaya yang perlu terus menerus dilakukan tanpa henti. Karena, potensi dan arti manajemen bagi keberlanjutan dan kebermanfaatan. 
Sebelum lebih jauh membahas tentang manajemen zakat, disini perlu dipahami terlebih dahulu bahwa membahas zakat dari optik manajemen saat ini sangat menarik perhatian banyak kalangan praktisi zakat di Indonesia. Menurut Lewis (2004) manajemen diartikan sebagai proses administrasi, dan koordinasi sumberdaya secara efektif dan efisien untuk meraih target dan tujuan organisasi (management is the process of administering and coordinating resources effectively and efficiently in an effort to achieve the goals of organisation).

Azizy (2004) mendefinisikan manajemen sebagai sebuah proses kerja yang melibatkan beberapa orang atau kelompok untuk mencapai tujuan tertentu. Dalam konteks ini, pengertian manajemen zakat bisa dipahami dari berbagai sisi rencana strategis (planning), organisasi sumberdaya (organizing), implementasi pelaksanaan (actuating), dan langkah evaluasi (evaluating) hal ihwal zakat. Ibn Taimiyah menyatakan bahwa manajemen zakat disalurkan dengan berpijak sebagaimana yang dilakukan di zaman para sahabat Nabi, yakni bukan untuk memproduksi masyarakat yang pemalas, konsumtif, dan tidak produktif, tetapi justru melalui zakat diharapkan sesuai dengan kebutuhan riil mustahiqnya. Disinilah perlu dihayati diferensiasi antara kebutuhan dan keinginan. Tentu saja, distribusi zakat lebih berbasis kepada kebutuhan masyarakat (mustahiq), bukan keinginan ansich. Semua itu, berujung pada satu titik keadilan bukan ketimpangan dan konflik politik kepentingan.

Islam hadir dengan sistem sekaligus solusi nyata melalui bergbagai ajaran dan amalan, termasuk zakat yang memungkinkan terciptanya tatanan masyarakat yang harmonis, mandiri, sejahtera dan berkelanjutan. Manajemen zakat bisa lebih optimal ketika dikelola melalui organisasi zakat yang profesional, dibanding dilakukan oleh individu-individu. Contoh nyata dan keberhasilan pengelolaan zakat yang berdampak hebat telah dipelopori sendiri oleh Nabi Muhammad dan Khulafa'ur Rasyidin melalui berbagai cara optimalisasinya pada zamannya. Dalam konteks Indonesia, tentu saja diharapkan bisa mengambil pelajaran dan keteladanan manajemen zakat yang pernah diselenggarakan oleh para nabi, 
meski tetap perlu dielaborasi sesuai dengan perkembangan terkini di dalam negeri.

Dewasa ini kemiskinan semakin disadari sebagai masalah global. Karena itu, perlu pula membuka pemikiran pendayagunaan sistem zakat untuk membidik masalah kemiskinan secara global. Fatwa yang konservatif (Syafi'i) melarang pemindahan harta zakat dari wilayah zakat itu dipungut. Batasannya bahkan amat sempit, yakni sebatas marhalah, jarak yang menjadi batas dibolehkannya qashar shalat.

Menghadapi masalah kemiskinan yang mengglobal, pembatasan semacam itu justru dapat menghambat potensi zakat itu sendiri. Mazhab-mazhab fikih yang lebih longgar dalam masalah zakat perlu dielaborasi lebih jauh untuk menghadapi tantangan global ini. Sebagian besar negara Islam adalah negara miskin yang terbelit utang. Pada saat yang sama, ada segelintir negara petrodollar yang berkelimpahan. Jika ada bantuan internasional yang benarbenar merupakan tashorruf (penyaluran) zakat, itu tentu tidak akan mengandung "jerat kepentingan modal" milik negara-negara kaya. Negara-negara miskin sungguh akan amat tertolong.

Manajemen zakat di Indonesia bisa dibagi menjadi dua: Manajemen tradisional dan modern-profesional. Manajemen yang pertama bisa ditandai dengan cara pengumpulan dan penyaluran zakat dengan sendiri-sendiri tanpa ada koordinasi satu sama lain. Biasanya hanya dibagi ke tetangga sekitar dan sifatnya parsial. Berbeda dengan yang pertama, manajemen yang kedua dikatakan sebagai modern-profesional, karena cara pengelolaan mulai pengumpulan hingga penyalurannya tidak semata-mata untuk tetangga tetapi untuk semua yang memerlukan. Secara substantif, hal ini diarahkan untuk pemberantasan kemiskinan di masyarakat secara luas. Lebih dari itu, biasanya menggunakan beberapa strategi fundraising. Ada beberapa strategi fundraising yang bisa diaplikasikan: 1) Strategi Marketing, meliputi: personal selling, brosur, infak kemanusiaan, promosi. 2) Strategi Receiving, meliputi: penerimaan di kantor, bank, dan amil zakat. 3) Strategi Struktural. Strategi ini melibatkan stuktur yang ada dengan cara profesional. 
4) Strategi Transformatif. Strategi transformasi lebih pada pelatihanpelatihan untuk mewujudkan kemandirian dan kesejahteraan umat.

\section{Gerakan Baru Filantropi Islam Tionghoa di Surabaya}

Umat Islam Tionghoa di Surabaya terus berupaya melakukan berbagai gerakan kepedulian sosial, kesehatan, pendidikan dan lainnya. Ini merupakan gerakan filantropi baru dalam pelayanan masalah keumatan, kemanusiaan dan kebangsaan. Hilman Latief (2010) memberikan solusi alternatif dalam pelayanan umat atas berbagai kasus dan permasalahan kemiskinan di pinggiran kota yang menempatkan gerakan sosial Muhammadiyah sebagai model gerakan filantropi modern yang merespon realitas kemiskinan di area urban. Menurut Hilman, gerakan filantropi Islam, kerelawanan, dan tanggung jawab sosial bisa dipraktekkan dengan optimal sikap kedermawaan dan gerakan filantropis.

Di komunitas Muslim Tionghoa di Surabaya juga ada gerakan semacam ini. Gerakan baru zakat kini menemukan momentumnya, karena berbagai alasan, argumentasi, situasi dan kondisi tertentu. Sebagaimana dimafhumi bersama bahwa jumlah penduduk Indonesia lebih dari 220 juta orang dan jumlah kaum muslimnya sekitar 80 persen. Dari angka 80 persen tersebut ada umat Islam yang berasal dari etnis Tionghoa di Indonesia. Secara umum, umat Islam di Indonesia bukanlah termasuk umat yang semua mapan secara ekonomi. Sebagian tergolong yang mempunyai kemampuan terbaik. Mengutip kajian Eri Sudewo (2006) bahwa penghasilan terkecil dari muzakki Rp 2 juta per-bulan, 2,5 persennya sekitar Rp 50 ribu. Dengan jumlah 18 juta keluarga muslim yang kaya, potensi terburuk tercatat zakat terendah sebesar Rp.90 M/ bulan. Jika ditotal, maka diperoleh Rp 1,08 T, per tahun.

Bisa dipahami dari jumlah angka tersebut menunjukkan bahwa ada sekitar 10 persen orang muslim yang kaya dari 90 juta, yang menunaikan zakat. Sisanya, skitar 81 juta orang kaya muslim lainnya belum membayar kewajiban zakat. Diasumsikan jika orang muslim kaya membayar zakat, maka angka jumlah input dari dana zakat diperoleh sekitar Rp 900 M/ bulan. Bisa dijumlah dana masuk 
setiap tahun sekitar Rp 10,8 T. Asumsi terburuk di atas masih sangat jauh dari kenyataan. Menurut Eri Sudewo mengacu pada data FOZ tahun 2005 menunjukkan ke publik tentang jumlah total dana zakat di Indonesia hanya berkisar Rp 12,5 M/ bulan atau Rp $250 \mathrm{M} /$ tahun. Itupun sudah termasuk infaq, shadaqah dan wakaf. Pertanyaannya kenapa bisa terjadi seperti itu? Oleh karena itu, di tahun berikutnya sampai saat ini, banyak evaluasi yang dilakukan oleh pemerintah dan lembaga zakat untuk melakukan evaluasi dan optimalisasi untuk menjawab problematika yang ada.

Dalam konteks ini, gerakan pencerahan dalam memaksimalkan gerakan baru berzakat di negeri ini perlu terus didorong semua pihak. Hafidhuddin (2002) mengungkapkan bahwa tujuan gerakan zakat bisa menciptkan kondisi ekonomi bangsa yang lebih baik. Berita baiknya ketika mengalami musibah dan masalah, umat Islam di Indonesia selalu responsif dan tergugah untuk menjadi relawan dan donatur. Idealnya, seharusnya tidak berhenti dengan permasalahan insidental. Rasanya diperlukan upaya dan gerakan antisipatif ketimbang reaktif. Berbagai model Social Responsibility (CSR) di dalam masyarakat bisnis maupun pemerintah untuk menyisihkan gaji karyawan muslim untuk zakat maupun infak tanpa harus membayar beban pajak dari gaji bulanannya, perlu dibahas dan digagas lebih optimal.

Hilmy (2008) menengarai perlu adanya gerakan substansiasi berbasis nilai ajaran agama yang bermakna dan bermanfaat bagi masyarakat luas, melalui berbagai agenda setting sosial, budaya, agama, lembaga pendidikan dan lainnya. Baidhawy menganjurkan adanya gerakan dan upaya trend-setting filantropi Islam melalui berbagai usaha yang kreatif dan inovatif. Tentunya semua pihak pemangku gerakan zakat juga perlu mendorong terbangunnya lembaga pengelola zakat yang bekerja dengan sungguh-sungguh, profesional dan optimal. Juga sudah saatnya, manajemen sumber daya manusia yang handal, amanah dan akuntablitasi dan transparansi keuangan muzakki terhadap publik luas, perlu terus dijadikan budaya yang baik. Institusi dan organisasi pengelolaan zakat dan sejenisnya juga perlu didorong untuk menjadi problem solver atau part of solution dari berbagai masalah promosi, sosialisasi, persuasi, 
organisasi, hingga distribusi zakat ke arah bukan konsumtif saja, tetapi juga lebih sistemik, efektif, produktif dan strategis. Dalam konteks marketing, sosialisasi zakat bisa menggunakan banyak cara dan media strategis berbasis teknologi informasi atau media sosial lainnya yang kini sedang berkembang dan diakses oleh banyak kalangan umat Islam yang memungkinkan untuk termotivasi dalam berzakat dan bersedekah.

Upaya yang dilakukan oleh umat Islam Tionghoa di Surabaya juga menggunakan cara sosialisasi di masjid Cheng Hoo Surabaya. Selain itu juga berbagai upaya merangkul para da'i/muballigh atau penceramahnya untuk mempersuasi jamaah dalam bersedekah dan berzakat. Hal itu juga dilakukan pada saat momentum jum'atan dan pengajian. Materi khutbah sudah didesain sedemikian rupa mengenai inspirasi dan motivasi keutamaan berzakat, infaq dan amal sedekah serta gerakan filantropi Islam lainnya yang berbasis sosial keagamaan.

Manajamen informasi dan sosialiasi sudah dilakukan oleh komunitas Muslim Tionghoa di Surabaya. Hasilnya, kesadaran umat Islam meningkat, karena pengaruh dari isi pesan penuh makna dan manfaat dari inspirasi, motivasi, dan sosialiasi yang dilakukan melalui berbagai cara, media dan strategi menarik. Disadari bahwa hal ini merupakan langkah awal yang nyata. Kemauan dan kemampuan pelayanan umat bagi setiap institusi dan individu umat Islam Tionghoa yang terkait zakat terus dinantikan oleh semua elemen masyarakat muslim Tionghoa. Akhirnya, juga disadari bahwa sinergi dan kerjasama semua pihak diperlukan demi mewujudkan masyarakat yang maju, makmur dan sejahtera.

\section{Kesimpulan}

Dari kajian lapangan tersebut di atas, ada beberapa kesimpulan penting yang perlu diketahui: Pertama, zakat sebagai salah satu model filantropi Islam di komunitas Muslim Tionghoa di Surabaya merupakan ikhtiar menjalankan sebagian rukun Islam sekaligus kewajiban sebagai wujud kepedulian sosial dan usaha mewujudkan 
harmoni dan kesejahteraan umat. Kedua, umat Islam Tionghoa di Surabaya mencoba berbagai strategi pengelolaan zakat melalui banyak cara kreatif dan inovatif, baik dari sisi marketing, receiving, struktural, kultural maupun transformatif. Bahkan, saat ini manajemen pengelolaan zakat di komunitas Muslim Tionghoa di Surabaya juga melibatkan banyak media sosial berbasis teknologi informasi. Selain itu, ketiga, umat Islam Tionghoa di Surabaya menyadari bahwa kerja sama semua pihak sangat direkomendasikan dalam upaya menggapai kesuksesan fungsi dan optimalisasi zakat sebagai gerakan baru filantropi Islam di negeri ini sebagai media untuk menanggulangi kemiskinan, masalah kemanusiaan, mewujudkan harmoni sosial dan mensejahterakan umat di berbagai kawasan di tingkat lokal, nasional, regional dan bahkan internasional. Hingga kini, ikhtiar filantropi Islam di komunitas muslim Tionghoa terus berlanjut dengan harapan untuk mendukung program pemerintah dalam mengatasi masalah ekonomi umat dan mewujudkan kehidupan yang harmonis antara semua elemen masyarakat di negeri ini.

\section{Daftar Pustaka}

Abdullah, M. and Suhaib, Abdul Quddus. 2011. "The Impact of Zakat on Social life of Muslim Society". Pakistan Journal of Islamic Research, Vol 8.

Alfitri. 2005. "The Law of Zakat Management and Non-Governmental Zakat Collectors in Indonesia". The International Journal of Not-for-Profit Law, Volume 8, Issue 2.

Austin, David M. 2002. Human Services Management: Organizational Leadership in Social Work Practice, New York: Columbia University Press.

Azizy, A. Qodri. 2004. Membangun Fondasi Ekonomi Umat. Yogyakarta: Pustaka Pelajar. 
Baidhawy, Zakiyuddin. 2007. Islam Melawan Kapitalisme. Yogyakarta: Resist Book.

. 2007. "Building harmony and peace through multiculturalist theology-based religious education: an alternative for contemporary Indonesia”. British Journal of Religious Education, Vol.29, No.1: 15-30.

.2015. "Lazismu and Remaking the Muhammadiyah's New Way of Philanthropy". Al-Jami'ah: Journal of Islamic Studies, Vol. 53, No.2: 387-412.

Frances, Nic. 2008. The End of Charity: Time for Social Enterprise. Crows Nest: Allen \& Unwin.

Giddens, Anthony. 2000. The Third Way and its Critics. Cambridge: Polity Press.

Hallaq, WB. 2011. "Maqasid and the Challenges of Modernity". AlJami'ab: Journal of Islamic Studies, Vol.49, No.1.

Harahap, Syahrin. 1999. Islam: Konsep dan Pemberdayaan. Yogyakarta: Tiara Wacana.

Hafidhuddin, Didin. 2002. Zakat Dalam Perekonomian Modern. Jakarta: Gema Insani Press.

Hilmy, Masdar. 2008. Islam Profetik: Substansiasi Nilai-nilai Agama dalam Ruang Publik. Yogyakarta: Impulse dan Kanisius.

Idris, Safwan. 1997. Gerakan Zakat Dalam Pemberdayaan Ekonomi Umat: Pendekatan Transformatif. Jakarta: PT. Citra Putra Bangsa.

Inayah, Gazi. 2003. Teori Komprehensif Tentang Zakat dan Pajak. Yogyakarta: Tiara Wacana.

Kahf, Monzer. 2005. Ekonomi Islam; Telaah Analitik terhadap Fungsi Sistem Ekonomi Islam. Yogyakarta: Pustaka Pelajar. 
Latief, Hilman. 2010. Melayani Umat: Filantropi Islam dan Ideologi Kesejahteraan Kaum Modernis. Jakarta: PT Gramedia Pustaka Utama.

Lewis, Pamela. 2004. Management: Challenges For Tomorrow's Leaders. United States of America, Milwaukee College.

Mahfud, Choirul. 2016. Politik Pendidikan Islam di Indonesia. Yogyakarta: Pustaka Pelajar.

Mahfud, Choirul. 2015. Pendidikan Multikultural. Yogyakarta: Pustaka Pelajar.

Mahfud, Choirul. 2014. "The Role of Cheng Ho Mosque: The New Silk Road, Indonesia-China Relations in Islamic Cultural Identity". Journal of Indonesian Islam, Vol. 8 No.1: 23-38.

Mahfud, Choirul. "The Power of Syukur: Tafsir Kontekstual Konsep Syukur dalam al-Qur'an”. Epistemé: Jurnal Pengembangan Ilmu Keislaman, 9 (2), 377-400. http://ejournal.iaintulungagung.ac.id/index.php/epis/article/view/71

Mas'udi, Masdar Farid, dkk. 2004. Reinterpretasi Pendayagunaan ZIS Menuju Efektivitas Pemanfaatan Zakat Infaq Sedekah. Jakarta: Piramedia.

Nabawi, Ismail. 2009. Ekonomi Islam: Perspektif Teori, Sistem dan Aspek Hukum. Jakarta: Putra Media Nusantara.

Naisbitt, John. 1994. Global Paradox: Semakin Besar Ekonomi Dunia, Semakin Kuat Perusahaan Kecil. Jakarta: Binarupa Aksara.

Nasution, Harun. 1996. Islam Rasional: Gagasan dan Pemikiran. Bandung: Mizan.

Qardawy, Yusuf. 1999. Hukum Zakat. Jakarta: Litera Antar NusaMizan.

Qadir, Abdurrachman. 2001. Zakat dalam Dimensi Mahdhah dan Sosial. Jakarta: PT. Raja Grafindo. 
Rofiq, Ahmad. 2004. Fiqh Kontekstual; Dari Normatif Ke Pemaknaan Sosial. Semarang: Pustaka Pelajar.

Saidurrahman. 2013. "The Politics of Zakat Management In Indonesia: The Tension Between BAZ and LAZ". Journal of Indonesian Islam, Vol. 7, No 2.

ZTF, Pradana Boy. 2008. Fikih Jalan Tengah: Dialektika Hukum Islam dan Masalah-masalah Masyarakat Modern. Jakarta: Hamdalah. 